\title{
CONTROL OF THE INTERNET IN THE SYSTEM OF FUNCTIONS IN THE MODERN STATE
}

\author{
Konstantin V. Strukov \\ Legal officer of an IT company
}

\begin{abstract}
The article discusses the development of state functions concerning Internet. It focuses on the analysis of the main problems that impede the development of control function. The research suggests proposals for the development of such function by the state. Based on the studies, a forecast about the prospects for further strengthening of state control over the Internet has been made.
\end{abstract}

Key words: state control, virtual space, state functions, the Internet

Conflicts of interest. The authors declared no conflicts of interest.

Article received June 16, 2020

Article accepted June 30, 2020

\section{For citation:}

Strukov, K.V. (2020) Control of the internet in the system of functions in the modern state. RUDN Journal of Law. 24 (3), pp. 629-657. DOI: 10.22363/2313-2337-2020-24-3-629-657.

\section{Introduction}

The relevance of the article rests in the fact that functional approach to the issues of state control on the Internet allows to consider the main structural elements of the organization of such control and identify ways to improve them by developing proposals concerning the entire structure and individual parts in terms of their internal relations.

Such study is of certain current interest in the context of overcoming threats to public order emanating from the Internet (for example: fraud, espionage, computer vi-

(C) Strukov K.V., 2020.

This work is licensed under a Creative Commons Attribution 4.0 International License

https://creativecommons.org/licenses/by/4.0 
ruses, and other problems) through the development of effective forms of response to offenses in the virtual space in order to prevent them.

At the same time, there are very few works that investigate this issue.

When considering the functions of the state and their reflection in the society, we do not think about the role of the Internet in the first place. The analysis of modern technologically developed countries often ignores this axiomatic fact; it is not eliminated in the process of improving and functioning of the authorities, although insufficient attention to such topics in the information society seems harmful and unacceptable given the huge role of virtual space in the $21^{\text {st }}$ century. This is an additional argument confirming the relevance of the research topic.

The purpose of the study is to identify common patterns of development of state functions in the Internet environment.

Based on the goal, the following tasks are formulated: 1) determining the laws of development of state functions; 2) identifying forms of implementation of the functions of modern states in the field of control over the Internet; 3 ) investigating problems that impede the transfer of state functions on the Internet, as well as suggesting possible solutions; 4) forecasting the development of state functions in the field of control over the Internet.

In the process of the study, an extensive number of scientific methods was used: 1) logical methods (analysis, synthesis, induction, deduction, dialectics, abstraction); they helped structure the information obtained in the framework of this research; 2) functional method that allowed us to consider the control activities of modern states in the framework of the theory of functions; 3 ) historical method used to ensure the continuity of scientific knowledge and their study; 4) formal legal method contributing to the analysis of legislation on the issues of state control on the Internet; 5) statistical method that allowed citing relevant data, threats emanating from the Internet, as well as effectiveness of various forms of response to them.

As part of this work, an analysis of the main regulatory documents that address issues of state control on the Internet is carried out.

The following outcome of the study can be mentioned: 1) the fact of the existence of the control function of the state in the field of virtual space has been proved; 2) legal and non-legal forms of the state's control function in the field of virtual space have been identified, as well as models for their dispatch; 3 ) the main problems associated with implementation of the control function on the Internet are identified, and ways to solve them are proposed; 4) a forecast is made for the development of the state's control function in the field of virtual space, which, for objective reasons, is in the direction of its strengthening.

The results of the study are reflected in practice, confirmed by the legislation of the Russian Federation and foreign countries.

The theoretical output and practical implementation of the study are connected with the fact that the work enriches scientific knowledge in the field of the theory 
of state functions; it allows to formulate proposals for improving control through the Internet to ensure the rule of law.

In addition to the introduction, the article includes four chapters, conclusion, and bibliography.

\section{General issues of the theory of state functions}

The question of the advisability of introducing the category of state functions into the scientific circulation and considering various social phenomena on its basis was initially debatable and attracted both supporters and opponents.

At first glance, it seems easy to find arguments against the theory. There is no satisfying definition of the concept state function, no idea of their number, features, and essence. There is a problem of classifying certain aspects of state activity as strictly defined functions of the state. There is some politicization of this concept stemming from Marxist philosophy in terms of characterizing various states from the point of view of justice of their structure. There is a hypothesis that it substitutes the categories of task and goal of the state, which allowed some researchers to describe these phenomena with the help of the functional approach.

On the other hand, it should be noted that the above arguments, although they highlight a certain imperfection of the category of state functions, still do not allow to prove its complete failure.

Indeed, one can note the presence of various approaches to the definition of the concept and essence of the functions of the state that exist in domestic science. At the same time, most views boil down to the fact that the functions of the state represent the main areas of activity or state activities themselves. A limited number of basic approaches reduces the degree of uncertainty of the described phenomenon to an acceptable framework. Moreover, they are not antagonistic, and can be overcome. Indicative in this regard is the point of view expressed by Ernst Bernard Haas; he looked at the category function as a direction of activity that can cause certain consequences, and at the same time as activity aimed at performing a specific task (Haas, 1964:595).

Turning to the functions of the state from a political perspective can be used to prove superiority of some states and / or political regimes over others and be based on the subjective interests of the person carrying out such activities. As an example, we refer to the report of I.V. Stalin at the XVIII Congress of the VKP (b). In this document, the head of the Russian state placed the modern capitalist countries on a par with the states of the slave and feudal type; as an argument he used the thesis of commonality of their functions: internal (main) - to keep the exploited majority in submission; external (not main) - to expand the territory of the ruling class at the expense of other countries and protect it from external encroachments. In contrast, characterizing the USSR during the victory of the socialist system of economy, the speaker noted the dominance of people's masses as a class, which, in his opinion, was 
reflected in the fairer system of functions of the Soviet state that had replaced capitalism: the function of protecting socialist property from thieves and looters; the function of military defense of the Soviet system; the function of economic and organizational and cultural-educational work of state bodies. But even if the theory of functions is used for political purposes, it can also be used for state planning and thus be of real importance for the development of the country. In the above example, on the basis of the identified functions of the state, the main tasks were formulated for the party; they were specified in its direct activities and aimed to systematically improve the composition of the party, bring the governing bodies closer to the field activities, improve personnel policy, and develop the outreach activities (Vyshinsky, 1939:22).

Of course, the concept of state function was formed gradually, replacing in some cases the concepts of goal and task of the state. In fact, G.F. Shershenevich believed that based on the identified tasks of the state, it is possible to determine its fundamental goal. However, the need to expand the categorical apparatus seems doubtful (Fetyukov, 2014:33-43). At the same time, there is an opinion that has not been disproved so far; one of its proponents (I.S. Samoshchenko) asserts that we can better understand the type of a particular state and its essence through its functions (Samoshchenko, 1956:81).

It is necessary to recognize a significant number of different classifications of types of functions, within the framework of which, the functions of the state are subject to frequent changes and additions. Analysis of the educational literature on the subject of Theory of State and Law allows to distinguish in the domestic science the following established criteria for classifying the functions of the state and their most common types $\left.{ }^{1}: 1\right)$ depending on significance: basic and non-basic; 2) depending on the duration of the action: permanent and temporary; 3) depending on the scope of implementation: internal and external; 4) depending on the principle of separation of powers: functions of the legislative, executive and judicial powers; 5) depending on the type of state: functions of the state as a political and legal institution, functions of a certain type of state, functions of a particular state at a certain point in time; 6) depending on the territory of implementation: functions of the state as a whole and functions of its individual components; 7) depending on the social purpose: functions expressing the interests of individual layers of society, and functions expressing the interests of society as a whole; 8) depending on the spheres of public life: the functions of the state in the economic, political, spiritual, cultural, social spheres of society; 9) depending on political regime: functions of a totalitarian state, functions of an authoritarian state and functions of a democratic state. It can be argued that all classifications of state functions are not exhaustive and unconditional. However, they allow to reveal various aspects of the state's activity and the essence of this phenomenon.

\footnotetext{
${ }^{1}$ Strukov, K.V. (2019) Kontrol'naya funktsiya gosudarstva v sfere virtual'nogo prostranstva (na primere Rossiiskoi Federatsii) [The control function of the state in the field of virtual space (on the example of the Russian Federation)]. Dis... kand. yurid. nauk [Dis ... cand. legal of sciences]. Moscow. 37. (in Russian).
} 
Developing this topic with regard to the allocation of new functions of the state, as well as to determination of their nature, many authoritative researchers note that functions of the state have such a property as variability. In fact, V.E. Chirkin points out that "functions are determined by the main tasks of the state and may be different for different states and/or for the same state at different stages of its development" (Chirkin, 2007:352). The variability of the functions of the state is determined by the following fundamental factors: 1) the concrete historical stage of development of a state-organized society; 2) the domestic and foreign policy situation around the state; 3 ) understanding of the goals and objectives facing the state on the part of the political elite; 4) understanding classification and nature of the functions of the state on the part of researchers of these phenomena.

Taking into account, the historical experience of the Russian Federation and realities of the $21^{\text {st }}$ century, it is urgent to raise the issue of the control function of the Russian state in the field of virtual space; it is proposed to understand it as the main directions of state control over information and information relations that take place on the Internet. A similar conclusion can be drawn about many other technologically advanced countries of our time. The state control over the Internet is so important for them that it should be considered as an independent area of their activity, presenting it as one of the functions and gradually moving away from the scientific position, according to which control is an exclusively serving element of the system functions. In most modern countries, official documents exist often in relation to general cybersecurity issues, confirming recognition of state control in the virtual space as an independent direction of the state's activity, in other words, its function (for example: The Doctrine of Information Security of the Russian Federation, US Cyber Strategy, Law on Internet Security of China, Canadian Cybersecurity Strategy, etc.) (Kazarin, 2013:58-74).

It can be noted that this function has its own specific features, which are identified in the framework of its empirical analysis. Its main goal is to ensure the rule of law in the virtual space, by which it is proposed to understand the totality of information and public relations that take place on the Internet, as well as information and telecommunication technologies providing access to this network. It is characterized by such signs as universal, transboundary and technogenic. The unique task of this function is to counter offenses in virtual space. In addition, it is characterized by specific forms of exercise.

Summing up the present chapter, we state the control function of the state in the field of virtual space is relevant.

\section{Forms of control function of the state on the internet}

The issues of the forms of exercising state functions are particularly important. L.I. Kask noted that these matters are of much greater importance to the social sciences than is customarily attached to them (Kask, 1967:112). Forms of implementation of state functions are thereby the external expression of the internal essence 
of the state; it determines the laws of development and vital activity of this public entity. In legal literature, the concept of implementation of state functions as external manifestation of state functioning, the ways and means of carrying out practical activities of the state aimed at realizing its goals.

Among various ways of classifying the forms of implementation of state functions, one of the most relevant basic criteria for gradation are the methods of activity of state bodies in exercising its functions. According to M.I. Baitin, it is proposed to distinguish within the framework of this classification the legal forms of exercising the state functions (associated with the issuance of regulatory legal acts entailing legal consequences) and the non-legal forms of exercising the state functions (reflected in state activities that are similar in their external features and related to the issuance of legal acts, not entailing legal consequences) (Baytin, 1969:267-270).

It is worth noting that the forms of implementation of the control function of the state in the field of virtual space differ from the known forms by the presence of their specificity. The validity of this thesis is due to the fact that state control in the field of virtual space is carried out directly behind the information and the relations that take place on the Internet.

In relation to the Russian Federation, the author considers the following legal forms of the state's control function in the field of virtual space: 1) creating and maintaining special state registers on certain issues of ensuring state control over virtual space; 2) licensing of certain types of activities in the field of communications and mass communications; 3 ) organizing storage and access to information posted on the Internet; 4) monitoring of virtual space; 5) verifying reports on offenses committed on the Internet; 6) blocking access to sites containing prohibited information. The author also defines the following main non-legal forms of exercising the state's control function in the field of virtual space within the Russian Federation: 1) developing and implementing information and telecommunication technologies to realize the control function of the Russian state in the field of virtual space; 2) organizing preventive measures aimed at improving the legal culture of citizens when working with the Internet; 3 ) increasing the level of professionalism of officials of state authorities responsible for implementing control function of the Russian state in the field of virtual space; 4) creating international collective security systems in the field of virtual space. Conclusions are made based on empirical analysis of various forms of implementing this function in terms of frequency of its use by public authorities and their efficiency proposed by the author of this article ${ }^{2}$. Forms of the control function in the field of virtual space are implemented by specialized state bodies related to the executive branch of government. Here are some relevant examples: Federal Service for Su-

\footnotetext{
${ }^{2}$ Strukov, K.V. (2017) Sposoby osushchestvleniya kontrol'noi funktsii rossiiskogo gosudarstva v sfere virtual'nogo prostranstva: analiz i perspektivny razvitiya [Methods of implementing the control function of the Russian state in the field of virtual space: analysis and promising development]. Humanities scientific researches. 2017. No. 6, available at: http://human.snauka.ru/2017/06/24149 (Accessed 29 February 2019). (in Russian).
} 
pervision of Telecommunications, Information Technologies, and Mass Communications in the Russian Federation, NSA in the USA, NKRSI in Ukraine. Often, other executive authorities also participate in the control of information on the network within their competence. For example, in the Russian Federation there is a specialized Office "K" under the Ministry of Internal Affairs, in the USA the CIA and the FBI, in Ukraine SBU.

At the same time, the practical plane of the forms of exercising the state's control function in the field of virtual space is such that the main powers for their implementation can be delegated to non-profit organizations controlled by the government, but not to state authorities. For example, in the DPRK, control over the Internet, as well as its national counterpart, Kwanmen, is primarily handled by the nonprofit organization Korean Computer Center, which has branches in some countries, including China, UAE, Syria, and several other states (Shatilina, 2018:38-45). As part of their activities, these government bodies and their respective units monitor the Internet.

The most important niche in terms of the forms of implementation of the control function of states in the field of virtual space is occupied by specialized programs that allow the following activities to be carried out: 1) tracking content according to specified parameters; 2) blocking access to prohibited content; 3) organizing collection of content according to the established characteristics. One can cite a number of examples of such programs, taking it as an axiom that they exist in one form or another in almost all developed modern countries: SORM in the Russian Federation, Tempora in the UK, PRISM in the USA, CMS and NETRA in India, Titan in Sweden. Often, the success of the entire system of state control of the Internet depends on the mechanisms of implementation, operation, and effectiveness of such programs, which determines their paramount importance in this matter, as well as the need to concentrate efforts to improve them.

The outcome of this chapter can be outlined as follows: legal and non-legal forms of the state's control function in the field of virtual space have been identified, and models of sending entities have been established.

\section{Problems related to the implementation of the control function over the internet}

The need to improve the control function of the state on the Internet is associated with the following global problem - the growth of crimes committed using the Internet. As follows from the statistics collected by the ATP "Garant", the question "Have you faced cybercrime?" was answered positively by $86 \%$ of respondents ${ }^{3}$. According to the statement made by the Head of the Main Directorate of Economic Se-

\footnotetext{
${ }^{3}$ Official site of ATP "Garant”, available at: http://forum.garant.ru/?read,4,1974918 (Accessed 03 March 2020).
} 
curity and Anti-Corruption of the Russian Ministry of Internal Affairs, Police Lieutenant General A.A. Kurnosenko, in 2019, in Russia every seventh crime is committed with the help of $\mathrm{IT}^{4}$. Cybersecurity Ventures experts claim that in 2019, cyber attacks occurred in the world every 14 seconds $^{5}$.

Practice shows that many modern countries claim that the available in their arsenal IT tools for monitoring virtual space are too imperfect. In fact, the above is true for specialized programs that allow monitoring activities. As an example, it can be noted that Russian virtual space control programs, as similar foreign programs, do not allow to decrypt information created by certain encoding methods, such as end-toend encryption used by the "Telegram» (Tereshchenko, 2018: 142-161). The Great Chinese Firewall example makes it obvious that this and similar programs can be bypassed using VPN services, which was demonstrated by one of the developers of the Golden Shield, programmer Fan Binshin, using the Tianhe service back in $2016^{6}$. As practice shows, these two problems, receiving and filtering / blocking certain information, are the most significant in this issue. Moreover, attempts to solve them, lying in the plane of creation and implementation of more advanced technologies, require significant financial costs. Certain trends in this area will be discussed in the next chapter of the study.

The traditional way for any state to respond to offenses is to hold perpetrators accountable for violations on the Internet; it is significantly difficult because modern technology allows to anonymously commit offenses from anywhere in the world, including locations where certain acts are not punishable, in contrast to the laws of those countries where they are actually committed through the World Wide Web.

In fact, they are trying to solve this problem by building a system of international cooperation and unifying legislation in the field of combating offenses in the virtual space and controlling it. At the multilateral level, the $108^{\text {th }}$ Council of Europe Convention can be cited as an example; at the bilateral level, the 2015 agreement between the Russian Federation and China on ensuring information security is worth mentioning. At the same time, it seems that some countries, the Russian Federation including, could advance in solving this problem by creating controlled non-profit organizations of an international nature and a network of their branches in foreign jurisdictions; this way they could monitor the virtual space and respond to offenses affecting national interests of those states, taking into account the specific legislation of those countries, including legal response measures (for example, submitting applications in the law enforcement agencies of foreign states). By means of public organizations, it is possible to solve not only the problem of bringing to responsibility for offenses on the Internet, but

\footnotetext{
${ }^{4}$ The official website of the Ministry of Internal Affairs of Russia, available at: https://xn--blaew.xn-p1ai/news/item/19087056 (Accessed 03 March 2020).

${ }^{5}$ The official website of the Federal State Unitary Enterprise RAMI "RIA NEWS", available at: https://ria.ru/20190522/1554794105.html (Accessed 03 March 2020).

6 "Vedomosti" official website, available at: https://www.vedomosti.ru/opinion/articles/2018/04/25/767754kak-ustroen-faeirvol (Accessed 03 March 2020).
} 
also the problem of improving the information ecology in virtual space, as well as legal and cultural education, by leaving relevant comments on social networks and other similar ways that are currently not attracting much attention.

Strengthening the state presence in the virtual space is an important part of the development of the information society, since ensuring national interests would be a very difficult task without it. A significant problem along this path is the reputational risks of the state associated with the strengthening of state control on the Internet. Any state that positions itself as a legal state is forced to balance between a protective policy aimed at introducing control restrictions and a liberal policy that represents a certain degree of independence for citizens when they exercise their rights and freedoms in the context of information relations arising on the Internet. In addition, from the above it follows that in case of a violation of the balance in favor of the "protective policy", the state risks its reputation as a "democratic policy". The adoption of normative legal acts that in any way restricts the capabilities of users of the World Wide Web can be opposed by 1) representatives of civil society, 2) foreign states, 3) international organizations. As an example of a similar situation when all of the three of the above levels the state, which had introduced tough state control measures over the virtual space of the global computer network, suffered reputational damage, we should mention the scandal with "spy revelations" made in 2013 by the former CIA officer Edward Snowden. The information he disclosed about the PRISM program, as well as about some other activities of the American special services aimed at ensuring state control over the exchange of information taking place on the Internet, led to wide public resonance and influenced the USA political image as a democratic state capable of supporting its national security and also respecting human rights (Gazizov, 2013:24-40). In our opinion, the aforementioned scandal, as well as similar cases, can be described by the term the Snowden Effect: a situation where a public message about strengthening of state control over the private life of citizens on the Internet is perceived by the latter as a violation of their constitutional right, which leads to a rise in protest activity and a fall in public trust in the state. In general, we believe that in modern conditions the right to privacy should exist provided that government officials have access to information created by users of the Internet, and such information is not arbitrarily used, including for the purpose of public disclosure. This will significantly increase the level of information security. It is also important to give legitimacy to the decisions made.

There is a problem of introducing civil society into the process of controlling the Internet. It should be noted that in the modern world there are public organizations whose activities are to identify offenses on the Internet through monitoring the information contained in it. For example, on the basis of the Public Chamber of the Russian Federation a monitoring center "Security 2.0" was set up; its direct task is to monitor the Internet to identify sites containing prohibited information, followed by 
reporting them to Roskomnadzor. Periodically, monitoring raids are also organized by public chambers of the constituent entities of the Russian Federation ${ }^{7}$. Organizations similar in their tasks exist in other countries. For example, in the UK there is an organization called Papyrus, which conducts Internet monitoring to close sites promoting suicide, and an Internet Monitoring Organization that monitors the network to identify sites containing extremist information. In Canada, a nonprofit organization called the Canada Child Protection Center carries out similar activities. There is also an organization that monitors virtual space for information security in the China China's Cybersecurity Association. In the context of globalization, some organizations monitoring the virtual space are international in nature. For example - NetBlocks. From the point of view of the sphere of its control, all non-profit organizations can be divided into two types: 1) organizations that monitor the virtual space in order to suppress any illegal activity, 2) organizations that monitor virtual space in order to suppress strictly defined types of illegal activities (for example, child pornography, online fraud, illegal trafficking of narcotic drugs and psychotropic substances). There are several special issues in this area. First, it can be assumed that representatives of non-profit organizations cannot have the same level of competence as government employees, and this can lead to errors in the legal assessment of specific circumstances and low work efficiency. As counterarguments, it can be noted that nonprofit organizations do not often have the same wide range of powers as government officials, and the lack of professional skills can be solved by organizing appropriate advanced training courses. Another problem is more academic in nature. It consists in the fact that, according to some researchers, civil society institutions should not be created by the state, since this contradicts their essence and, in this case, they cease to express "people's will". However, one can propose an alternative concept of civil society, which the author conditionally calls state. From the point of view of a rational approach and within the framework of the goal of ensuring the rule of law in the virtual space, financial (in particular, grants, subsidies), organizational, administrative, and media support of public organizations by the state is a very common phenomenon, examples of which are repeatedly cited in this article. It should be recognized that the state can create / participate in the process of creation the institutions of civil society that it needs, relying on those representatives of society that are loyally disposed towards it; non-profit organizations created / functioning in this way do not automatically fall out of the orbit of civil society, because, performing social state orders are often able to reflect the interests of citizens, as well as be formed on a voluntary basis by the latter, seeking at a certain stage of their development the support from public authorities to achieve their goals. Thus, the problem of the effectiveness of non-profit organizations monitoring the Internet can be solved by using the above forms of government support.

\footnotetext{
${ }^{7}$ Official site of the Public Chamber of the Russian Federation, available at: https://www.oprf.ru/ ru/press/news/2017/newsitem/42692?PHPSESSID=m1v88m9fnerk651ud8g73pfl95 (Accessed 03 March 2020).
} 
Summing up, we can outline the following results of this chapter. The main problems associated with the implementation of the control function on the Internet have been identified, they are connected with the active growth of offenses committed via the Internet; imperfection of control mechanisms and technologies in the field of virtual space; the growth of public discontent associated with strengthening state control on the Internet; difficulties in attracting civil society institutions to the process of exerting control on the Internet.

\section{Forecasting the development of the state function in the field of control over the internet}

In recent history, the starting point of the trend to strengthen state control over the Internet is associated with the very beginning of the $21^{\text {st }}$ century, which, in our opinion, is connected with the USA where George Bush Administration adopted the Patriotic Act 2001 as a response to $\langle 9 / 11 »$ events. Many other countries, such as the Russian Federation and China, adhere to this practice. Author believes that given the growing role of the World Wide Web in the information society, as well as the relevance of the threats emanating from it, in the forthcoming decades the state's control function in the field of virtual space will grow.

Despite the large financial costs, significant budgetary investments will be made in the development of programs that allow the implementation of the control function in the virtual space. This process will be closely linked to issues of ensuring state sovereignty on the Internet. We believe that many countries will directly oblige entities under their control to install the above programs on gadgets and other equipment providing access to the network. With regard to the Russian Federation, such a measure is possible within the framework of implementation of the provisions of the Federal Law dated 02.12.2019 No. 425-Ф3 On Amending Article 4 of the Law of the Russian Federation On Protection of Consumer Rights, which prescribes the mandatory pre-installation of Russian software on gadgets sold in the framework of sales contracts in the Russian Federation, according to the schedule approved by the authorities. It is quite possible to include these programs in such schedule. In the most radical cases, there will be attempts to ensure complete control of their virtual space or at least the autonomy of the national Internet from the external network, as is now the case in the Russian Federation under the Law on Sovereign Internet, as well as in China, where the experience of the DPRK in this matter is closely studied. Here are other examples: in Myanmar, access to the Internet is only possible in licensed Internet cafes controlled by the government; in the whole country of Turkmenistan there is only one authorized provider controlled by the state (Dashyan, 2007:288).

In this regard, a trend will develop that consists in increasing the list of duties of information intermediaries related to the provision concerning state control over the Internet and establishing a regime of legality in the virtual space, as well as toughening responsibility for their non-fulfillment. As an example, we refer to EU 
legislation. In 2019, it received the approval of the European Parliament and the Council Directive on copyright and related rights within the framework of a single digital market, which contains Article 13, called the "download filter", which stipulates the obligation of owners of online platforms to install software filters to prevent copyright infringement on the Internet. It is noteworthy that this article has become one of the most controversial in this document, along with Article 11, called the "tax on links" (establishes the obligation of Internet platforms to pay royalties to publications for quoting their materials) (Eremenko, 2019: 9-22). As a result, the tendency of periodic criticism of states by Internet users is inevitable, as well as their growing dissatisfaction with the tightening of control in the virtual space. Countries will often experience the Snowden Effect. The solution to the problem is possible by building an effective system of working with public opinion, aimed at highlighting the need for state control on the Internet from the point of view of the interests of not only the state, but also society (Strukov, 2016:142-144).

At the level of interstate cooperation and geopolitical associations, cooperation will be strengthened, and legislation will be unified in the field of combating offenses using information and telecommunication technologies.

As an echo of the above issues, it is possible that a system of non-profit organizations involved in monitoring the Internet will gradually build up. This system should include interstate aspect as well. This can be expressed in the increase in the number of international organizations initially based on one or more countries that will engage in these activities on an ongoing basis. On the other hand, the emergence of non-profit organizations advocating the freedom of the Internet from state control and ensuring an "information environment" can be used to hinder the development of countries by their competitors; this may as well increase the state's reputation costs through formation of negative public opinion concerning strengthening such control (Strukov, 2016:267-270).

Thus, this chapter predicts the development of the state's control function in the field of virtual space, which, for objective reasons, tends to strengthen.

\section{Conclusion}

The control function in the field of virtual space is a given reality that exists for all the strong and technologically advanced states of our time. Its appearance is an answer to global problems of the $21^{\text {st }}$ century, the solution of which requires a state presence and enhanced control on the Internet. This function characteristic features, purpose and forms of implementation are inherent. The process of its development is accompanied by certain problems; one of them is the need for continuous improvement of information and telecommunication technologies in performing control activities, which requires significant costs. In general, to prevent threats to information security, the state needs to tighten control in the field of virtual space. However, strengthening of state control over the Internet is often negatively perceived by socie- 
ty, and therefore there is a request for additional mechanisms to legitimize state power decisions in this area.

\section{References / Библиографический список}

Baytin, M.I. (1969) O formakh osushchestvleniya funktsii sotsialisticheskogo gosudarstva [On the forms of implementation of socialist state functions]. Uchenye zapiski SyUI of D.I. Kursky. Saratov. Issue 18. 267-270. (in Russian).

Байтин М.И. О формах осуществления функций социалистического государства // Ученые записки СЮИ им. Д.И. Курского. Саратов, 1969. Вып. 18. С. 267-270.

Chirkin, V.E. (2007) Yuridicheskoe litso publichnogo prava [Legal entity of public law]. Moscow: NORMA Publ. (in Russian).

Чиркин В.E. Юридическое лицо публичного права. М.: НОРМА, 2007. 352 с.

Dashyan, M.S. (2007) Pravo informatsionnykh magistralei (Law of information highways): Voprosy pravovogo regulirovaniya $v$ sfere Internet [Law of information highways: Issues of legal regulation in the field of Internet]. Moscow: Walters Kluver Publ. (in Russian).

Дашян М.C. Право информационных магистралей (Law of information highways): Вопросы правового регулирования в сфере Интернет. М.: Волтерс Клувер, 2007. $288 \mathrm{c}$.

Eremenko, V.I. (2019) EU directive on copyright reform within the unified digital market framework. IP. Copyright and related rights. No 11.9-22. (in Russian).

Еременко В.И. Директива Евросоюза о реформе авторского права в рамках единого цифрового рынка // ИС. Авторское право и смежные права. 2019. № 11. С. 9-22.

Fetyukov, F.V. (2014) Evolution of ideas about the substance and content of the concept of «state functions». Vestnik Permskogo universiteta. Ser.: Juridicheskie nauki - Perm University Herald. Series: Yuridical Sciences. 3(25). 33-43. (in Russian).

Фетюков $Ф . B$. Эволюция представлений о сущности и содержании понятия «функции государства» // Вестник Пермского университета. Юридические науки. 2014. Вып. 3(25). C. 33-43.

Gazizov, R.R. (2015) Theoretical and methodological foundations of the legal protection of personal data in the Russian Federation and abroad. Legal World. No. 7. 39-41. (in Russian). Газизов P.P. Теоретико-методологические основы правовой защиты персональных данных в РФ и за рубежом // Юридический мир. 2015. № 7. С. 39-41.

Haas, E.B. (1964) Beyond the Nation-State. Functionalism and International Organization. Stanford: Stanford University Press.

Kask, L.I. (1967) O znachenii sotsial'nykh nauk [On the value of social sciences]. Jurisprudence. No. 6. 112. (in Russian).

Каск Л.И. О значении социальных наук // Правоведение. 1967. № 6. С. 112.

Kazarin, O.V., Tarasov, A.A. (2013) Modern concepts of cybersecurity of leading foreign countries. Bulletin of the Russian State Humanitarian University. Series: documentation and archiving. Computer science. Information protection and information security. No. 14. 58-74. (in Russian).

Казарин О.В., Тарасов А.А. Современные концепции кибербезопасности ведущих зарубежных государств // Вестник РГГУ. Серия: документирование и архивоведение. Информатика. Защита информации и информационная безопасность. 2013. № 14. C. $58-74$. 
Samoshchenko, I.S. (1956) O pravovykh formakh osushchestvleniya funktsii Sovetskogo gosudarstva [On legal forms of implementation of the Soviet state functions]. Soviet state and law. No. 3. 85-87. (in Russian).

Самощенко И.С. О правовых формах осуществления функций Советского государства // Советское государство и право. 1956. № 3. С. 85-87.

Shatilina, A.S. (2018) Human rights on the Internet: the problem of recognizing the right to access the Internet. Precedents of the European Court of Human Rights. No. 1. 38-45. (in Russian).

Шатилина А.С. Права человека в Интернете: проблема признания права на доступ к Интернету // Прецеденты Европейского суда по правам человека. 2018. № 1. C. $38-45$.

Sokolov, M.S. (2013) Some of issues of information protection constituting a military secret. ENI "Military Law". Issue No. 4. 24-40. (in Russian).

Соколов M.C. Некоторые вопросы противодействия угрозам информации, составляющей военную тайну // ЭНИ «Военное право». 2013. Выпуск № 4. С. 24-40.

Strukov, K.V. (2016) Control of the Russian state over the Internet: trends and development. Eurasian Law Journal. No. 10. 267-270. (in Russian).

Струков К.В. Контроль российского государства за сетью «Интернет»: тенденции и пути развития // Евразийский юридический журнал. 2016. № 10. С. 267-270.

Tereshchenko, L.K. (2018) State Control in Personal Data Protection. The journal "Pravo. Zhurnal Vysshey shkoly ekonomiki" [ "Law. Journal of the Higher School of Economics”]. No. 4. 142-161. DOI: 10.17323/2072-8166.2018.4.142.161. (in Russian).

Терещенко Л.К. Государственный контроль в сфере защиты персональных данных // Право. Журнал Высшей школы экономики. 2018. № 4. C. 142-161. DOI: 10.17323/ 2072-8166.2018.4.142.161.

Vyshinsky, A.Y. (1939) XVIII XVIII s"ezd VKP(b) i zadachi nauki sotsialisticheskogo prava [Congress of the VKP (b) and the tasks of the science of socialist law]. Soviet state and law. No. 3. 22. (in Russian).

Вышинский А.Я. XVIII съезд ВКП(б) и задачи науки социалистического права // Coветское государство и право. 1939. № 3. С. 22.

\section{About the author: \\ Konstantin V. Strukov - Candidate of Legal Sciences, Legal Officer, IT Company ORCID ID: 0000-0002-0592-8807}

e-mail: konstantinstrukov@gmail.com 


\title{
КОНТРОЛЬ ЗА СЕТЬЮ «ИНТЕРНЕТ» В СИСТЕМЕ ФУНКЦИЙ СОВРЕМЕННОГО ГОСУДАРСТВА
}

\author{
К.В. Струков \\ Сотрудник правового отдела ИТ-компании
}

\begin{abstract}
В статье рассмотрены вопросы развития функций государства в условиях существования сети «Интернет». Проведен анализ основных проблем, препятствующих развитию контрольной функции. Разработаны предложения по повышению ее эффективности. На основе проведенных исследований сделан прогноз перспектив ее дальнейшего развития в сторону усиления контроля в сети «Интернет».
\end{abstract}

Ключевые слова: государственный контроль, виртуальное пространство, функции государства, сеть «Интернет»

Конфликт интересов. Автор заявляет об отсутствии конфликта интересов.

Дата поступления в редакцию: 16 июня 2020 г.

Дата принятия к печати: 30 июня 2020 г.

\section{Для цитирования:}

Струков К.В. Контроль за сетью «Интернет» в системе функций современного государства // Вестник Российского университета дружбы народов. Серия: Юридические науки. 2020. T. 24. № 3. С. 629-657. DOI: 10.22363/2313-2337-2020-24-3-629-657.

\section{Введение}

Актуальность статьи заключается в том, что функциональный подход в исследовании вопросов государственного контроля в сети «Интернет» позволяет рассмотреть основные структурные элементы системы организации такого контроля, выявив способы их качественного улучшения посредством выработки предложений по совершенствованию как всей указанной структуры, так и отдельных частей, в разрезе ее внутренних связей и деятельности составляющих компонентов.

Проведение подобного исследования является востребованным в контексте преодоления угроз общественному порядку, исходящих от сети «Интернет» (например: мошенничество, шпионаж, компьютерные вирусы и т.п. проблемы) посредством выработки действенных форм реагирования на правонарушения в виртуальном пространстве с целью их пресечения.

При этом не представляется возможным сделать вывод о наличии значительного числа научных работ, в которых указанная тематика, востребованная в настоящее время, была бы исчерпывающим образом исследована. 
При рассмотрении в научной среде функций государства и особенностей его жизнедеятельности нередко забывается о существенном проявлении всех основных сфер жизни общества в сети «Интернет». Данный аксиоматичный факт при анализе современных технологически развитых стран часто игнорируется, не устраняется в процессе деятельности и совершенствования органов власти, хотя недостаточное внимание к подобной тематике в условиях информационного общества представляется пагубным и недопустимым с учетом огромной роли виртуального пространства в XXI веке. Это является дополнительным аргументом, подтверждающим актуальность темы исследования.

Цель исследования заключается в выявлении общих закономерностей развития функций государства в условиях существования сети «Интернет».

Исходя из поставленной цели, сформулированы следующие задачи: 1) Определение закономерностей развития функций государства; 2) Выявление форм осуществления функций современных государств в области контроля за сетью «Интернет»; 3) Установление проблем, препятствующих отправлению функций государства в сети «Интернет», а также возможных путей их решения; 4) Прогнозирование развития функции государства в области контроля за сетью «Интернет».

В процессе исследования был применен обширный перечень научных методов его проведения: 1) логические методы (т.е. анализ, синтез, индукция, дедукция, диалектика, абстрагирование), при помощи которых осуществлялось структурирование информации, полученной в рамках данной работы; 2) функциональный метод, позволивший рассмотреть контрольную деятельность современных государств в рамках теории функций; 3) исторический метод, использовавшийся для обеспечения преемственности научных знаний и их изучения; 4) формально-юридический метод, при помощи которого производился анализ законодательства, посвященного вопросам государственного контроля в сети «Интернет»; 5) статистический метод, с помощью которого, посредством приведения соответствующих данных, исследовались угрозы, исходящие от сети «Интернет», а также действенность различных форм реагирования на них.

В рамках написания работы проведен анализ основных нормативных документов, которые затрагивают вопросы государственного контроля в сети «Интернет».

В качестве основных результатов исследования можно представить следующие положения: 1) доказан факт существования контрольной функции государства в сфере виртуального пространства; 2) выявлены правовые и неправовые формы осуществления контрольной функции государства в сфере виртуального пространства, а также установлены модели их отправления; 3) определены основные проблемы, связанные с реализацией контрольной функции в сети «Интернет», предложены пути их решения; 4) сделан прогноз развития контрольной функции государства в сфере виртуального пространства, который по объективным причинам происходит в направлении ее усиления. 
Результаты исследования нашли отражение на практике, подтверждаясь законодательством Российской Федерации и зарубежных стран.

Теоретическая и практическая значимость исследования состоит в том, что работа обогащает научные знания в области теории функций государства, позволяет сформулировать предложения по совершенствованию контроля посредством сети «Интернет» для обеспечения режима законности.

Помимо введения, статья включает четыре раздела, заключение и библиографический список.

\section{Общие вопросы теории функций государства}

Вопрос о целесообразности введения в научный оборот категории «функции государства» и рассмотрения на ее основе различных социальных явлений изначально носил дискуссионный характер, имея как своих сторонников, так и своих противников.

На первый взгляд представляется возможным найти аргументы, свидетельствующие против такой необходимости. Отсутствует единое определение понятия «функции государства», представление об их перечне, признаках и сущности. Имеет место проблема отнесения тех или иных аспектов государственной деятельности к строго определенным функциям государства. Существует некоторая политизированность данного понятия, в частности использовавшегося в марксистской философии для характеристики различных государств с точки зрения справедливости их устройства. Наличествует гипотеза о подмене ею категорий «задачи» и «цели» государства, с помощью которых некоторым исследователям представлялось возможным описать все те же явления, что и при помощи функционального подхода.

С другой стороны, нельзя не отметить, что приведенные аргументы, хотя и указывают на определенное несовершенство категории «функции государства», все же не позволяют доказать полную несостоятельность ее существования.

Действительно, можно отметить наличие различных подходов к определению понятия и сущности функций государства, существующих в отечественной науке. В то же время большинство взглядов сводится к тому, что функции государства представляют собой основные направления деятельности или саму деятельность государства. Ограниченное число базовых подходов позволяет снизить степень неопределенности описываемого явления до приемлемых рамок. При этом они не находятся в состоянии антагонистического противоречия, преодоление которого представляет собой невыполнимую задачу. Показательна в этой связи точка зрения Эрнста Бернарда Хааса на категорию «функция», который рассматривал ее понятие как направление деятельности, могущее вызвать определенные последствия, и одновременно как деятельность, направленную на выполнение определенной задачи (Haas, 1964:595). 
Нельзя отрицать того факта, что обращение к функциям государства в политическом ракурсе может использоваться для доказывания превосходства одних государств и/или политических режимов перед другими, исходя из субъективных интересов лица, осуществляющего подобного рода деятельность. В качестве примера приведем доклад И.В. Сталина в рамках XVIII съезда ВКП (б). В указанном документе глава советского государства поставил современные капиталистические страны в один ряд с государствами рабовладельческого и феодального типа, для чего им использовался тезис общности их функций: внутренней (главной) - держать эксплуатируемое большинство в подчинении; внешней (не главной) - расширять территорию господствующего класса за счет других стран и защищать ее от внешних посягательств. В противовес этому, характеризуя СССР периода победы в нем социалистической системы хозяйства, докладчиком отмечалось господство представителей народных масс, как класса, что, по его мнению, находило отражение в более справедливой системе функций советского государства, пришедшей на смену капиталистической: функция охраны социалистической собственности от воров и расхитителей; функция военной защиты советского строя; функция хозяйственно-организаторской и культурновоспитательной работы государственных органов. Нельзя при этом не отметить, что даже в случае применения теории функций в политических целях она может использоваться для государственного планирования и таким образом представлять реальное значение для развития страны. В указанном примере на основании выявленных функций государства формировались основные задачи, ставившиеся перед партией, получавшие конкретизацию в ее непосредственной деятельности: систематически улучшать состав партии, приблизить руководящие органы к работе на местах, совершенствовать кадровую политику, развивать пропагандистскую деятельность (Vyshinsky, 1939:22).

Конечно, понятие «функция государства» формировалось постепенно, заменяя в некоторых случаях понятия «цели» и «задачи» государства. В частности, Г.Ф. Шершеневич полагал, что на основе выявленных задач государства можно определить его основополагающую цель. Вследствие этого необходимость расширения категориального аппарата представляется сомнительной (Fetyukov, 2014:33-43). Вместе с тем существует, не нашедшая опровержения точка зрения, разделяемая, в частности, И.С. Самощенко, согласно которой через функции государства можно лучшим образом понять тип конкретного государства, а также его сущность (Samoshchenko, 1956:81).

Нельзя не отметить и наличия значительного числа различных классификаций видов функций, в рамках которых к тому же функции государства подвержены частому изменению и дополнению. На основе анализа учебной литературы по предмету «Теория государства и права» автор пришел к выводу, что в отечественной науке можно выделить следующие устоявшиеся критерии классификации функций государства и их общие, наиболее часто встречающиеся виды: 1) с точки зрения значимости как критерия: основные и неосновные; 
2) в плане продолжительности действия: постоянные и временные; 3) в зависимости от сферы осуществления: внутренние и внешние; 4) с точки зрения соблюдения принципа разделения властей: функции законодательной, исполнительной и судебной власти; 5) в зависимости от вида государства: функции государства как политико-правового института, функции определенного типа государства, функции конкретного государства на определенный момент времени; 6) в рамках территории осуществления: функции государства в целом и функции отдельных его составных частей; 7) с позиции социального назначения: функции, выражающие интересы отдельных слоев общества, и функции, выражающие интересы всего общества в целом; 8) в зависимости от сфер общественной жизни: функции государства в экономической, политической, духовно-культурной, социальной сферах жизни общества; 9) в плане политического режима: функции тоталитарного государства, функции авторитарного государства и функции демократического государства. Можно утверждать, что все классификации функций государства не являются исчерпывающими и безусловными. Однако они позволяют раскрыть различные стороны деятельности государства и сущность данного явления.

Развивая данную тематику применительно к вопросу выделения новых функций государства, равно как и применительно к вопросу определения их сущности, многие авторитетные исследователи отмечают, что функциям государства присуще такое свойство, как изменчивость. В частности, В.Е. Чиркин указывает, что: «Функции определяются основными задачами государства и могут быть неодинаковыми у разных государств, у одного и того же государства на разных этапах его развития» (Chirkin, 2007:352). Изменчивость функций государства обусловлена следующими основополагающими факторами: 1) конкретно-исторический этап развития государственно организованного общества; 2) внутриполитическая и внешнеполитическая обстановка вокруг государства; 3) понимание целей и задач, стоящих перед государством, со стороны политической элиты; 4) взгляд на классификацию и природу функций государства со стороны исследователей данных явлений.

С учетом исторического опыта Российской Федерации и применительно к реалиям XXI века актуальной является постановка вопроса о наличии контрольной функции российского государства в сфере виртуального пространства, под которой предлагается понимать основные направления государственного контроля за информацией и информационными отношениями, имеющими место в сети «Интернет». Подобный вывод можно сделать и о многих иных технологически-развитых странах современности. Государственный контроль в условиях существования Всемирной компьютерной сети столь важен для них, что все отчетливее можно утверждать о целесообразности его рассмотрения в виде самостоятельного направления их деятельности, представляя в качестве одной из функций, постепенно отходя от научной позиции, согласно которой контроль является исключительно обслуживающим элементом системы функ- 
ций. В большинстве современных стран существуют официальные документы, косвенно, зачастую применительно к общим вопросам кибербезопасности, подтверждающие признание государственного контроля в виртуальном пространстве в качестве самостоятельного направления деятельности государства, а иными словами его функцией (например: «Доктрина информационной безопасности Российской Федерации», «Киберстратегия США», «Закон об интернетбезопасности КНР», «Стратегия кибербезопасности Канады» и т.п. документы) (Kazarin, 2013:58-74).

Можно отметить: указанной функции присущи свои специфические черты, что выявлено в рамках ее эмпирического анализа. Основная ее цель обеспечение режима законности в виртуальном пространстве, под которым предлагается понимать совокупность информации и общественных отношений, имеющих место в сети «Интернет», а также информационно-телекоммуникационных технологий, с помощью которых осуществляется доступ к данной сети. Ее характеризуют такие признаки, как: универсальность, трансграничность и техногенность. Уникальная задача этой функции состоит в противодействии правонарушениям в виртуальном пространстве. Кроме того, ей свойственны специфические формы осуществления.

Подводя итог настоящего раздела, констатируем факт доказанности существования контрольной функции государства в сфере виртуального пространства.

\section{Формы осуществления контрольной функции государства в сети «Интернет»}

Вопросы форм осуществления функций государства являются очень важными. В прошлом Леопольд Иоганович Каск обращал внимание, что данные вопросы представляют для общественных наук несомненно большее значение, чем им принято придавать (Kask, 1967:112). Все формы осуществления функций государства выступают тем внешним выражением сущности государства, которая предопределяет закономерности развития и жизнедеятельности этого публичного образования. В российской юридической литературе сложилось понимание форм осуществления функций государства как внешнего проявления функционирования государства, способов и средств осуществления практической деятельности государства, направленной на реализацию целей государства и решение стоящих перед ним задач.

Среди различных способов классификации форм осуществления функций государства нам представляется одной из наиболее актуальных та, в соответствии с которой базовым критерием градации выступают способы деятельности органов государства по реализации его функций. За основу взят подход М.И. Байтина, согласно которому предложено различать в рамках указанной классификации правовые формы осуществления функций государства (связаны 
с изданием нормативных правовых актов и влекут юридические последствия) и неправовые формы осуществления функций государства (заключаются в однородной по своим внешним признакам деятельности государства, связанной с изданием юридических актов, не влекущей за собой юридических последствий) (Baytin, 1969:267-270).

Уместно отметить, что формы осуществления контрольной функции государства в сфере виртуального пространства отличаются от известных форм наличием своей специфики. Верность данного тезиса обусловлена тем обстоятельством, что государственный контроль в сфере виртуального пространства осуществляется непосредственно за той информацией и теми отношениями, которые имеют место в сети «Интернет».

Применительно к Российской Федерации к числу основных правовых форм осуществления контрольной функции государства в сфере виртуального пространства автор относит: 1) создание и ведение специальных государственных реестров по отдельным вопросам обеспечения государственного контроля за виртуальным пространством; 2) лицензирование отдельных видов деятельности в сфере связи и массовых коммуникаций; 3) организация хранения и доступа к информации, размещенной в сети «Интернет»; 4) мониторинг виртуального пространства; 5) проверка сообщений о правонарушениях, совершаемых в сети «Интернет»; 6) блокировка доступа к сайтам, содержащим запрещенную информацию. Автор также определяет следующие основные неправовые формы осуществления контрольной функции государства в сфере виртуального пространства в рамках рассмотрения Российской Федерации: 1) разработка и внедрение информационно-телекоммуникационных технологий, при помощи которых может происходить отправление контрольной функции российского государства в сфере виртуального пространства; 2) организация профилактических мероприятий, направленных на повышение правовой культуры граждан при работе с сетью «Интернет»; 3) повышение уровня профессионализма должностных лиц органов государственной власти, отвечающих за реализацию контрольной функции российского государства в сфере виртуального пространства; 4) создание международных систем коллективной безопасности в сфере виртуального пространства. Выводы сделаны на основе эмпирического анализа различных форм осуществления указанной функции с точки зрения частоты использования органами государственной власти и предполагаемой автором настоящей статьи их эффективности.

Формы осуществления контрольной функции в сфере виртуального пространства реализуются специализированными государственными органами, относящимися к исполнительной ветви власти. Приведем несколько соответствующих примеров: Роскомнадзор в Российской Федерации, АНБ в США, НКРСИ на Украине. Зачастую в рамках своей компетенции иные исполнительные органы власти также участвуют в контроле за информацией в сети. Например, в Российской Федерации существует специализированное Управление «К» при МВД, 
в США - ЦРУ и ФБР, на Украине СБУ. В рамках своей деятельности указанные органы государственной власти и их соответствующие подразделения осуществляют мониторинг сети «Интернет».

При этом практическая плоскость форм осуществления контрольной функции государства в сфере виртуального пространства такова, что основные полномочия по их реализации могут делегироваться подконтрольным правительству некоммерческим организациям, а не органам государственной власти. Например, в КНДР контролем за Всемирной компьютерной сетью, а также ее национальным аналогом «Кванмен» прежде всего занимается некоммерческая организация Корейский компьютерный центр, имеющая филиалы в некоторых странах, включая КНР, ОАЭ, Сирию и ряд других государств (Shatilina, 2018:38-45).

Важнейшую нишу в плане форм осуществления контрольной функции государств в сфере виртуального пространства занимают специализированные программы, позволяющие осуществлять следующие мероприятия: 1) отслеживание контента по заданным параметрам; 2) блокировка доступа к запрещенному контенту; 3) организация сбора контента по установленным характеристикам. Можно привести ряд примеров таких программ, принимая за аксиому, что они существуют в том или ином виде практически во всех развитых государствах современности: СОРМ в РФ, Тетрога в Великобритании, PRISM в США, CMS и NETRA в Индии, Titan в Швеции. Зачастую от механизмов внедрения, эксплуатации, а также эффективности таких программ зависит успешность всей системы государственного контроля за сетью «Интернет», что обуславливает их первостепенное значение в указанном вопросе, а также необходимость концентрации усилий по их совершенствованию.

Итоги настоящего раздела: выявлены правовые и неправовые формы осуществления контрольной функции государства в сфере виртуального пространства, а также установлены модели отправляющих их субъектов.

\section{Проблемы, связанные с реализацией контрольной функции в сети «Интернет»}

Необходимость совершенствования контрольной функции государства в сети «Интернет» связана со следующей глобальной проблемой: рост преступлений, совершаемых с использованием сети «Интернет». Как следует из статистических данных, собранных СПС «Гарант», на вопрос, «Сталкивались ли Вы с киберпреступностью?» 86 \% респондентов дало положительный ответ ${ }^{8}$. Согласно заявлению Начальника Главного управления экономической безопасности и противодействию коррупции МВД России, генерал-лейтенанта полиции

\footnotetext{
${ }^{8}$ См.: официальный сайт СПС «Гарант, available at: http://forum.garant.ru/?read,4,1974918 (Accessed 03 March 2020).
} 
А.А. Курносенко, сделанному в 2019-м году, в Российской Федерации каждое седьмое преступление совершается при помощи ИТ-технологий 9 . Экспертами по кибербезопасности Cybersecurity Ventures утверждается, что в 2019-м году кибератаки происходили в мире каждые 14 секунд ${ }^{10}$.

Практика показывает: многие современные страны сталкиваются с тем, что имеющиеся в их арсенале ИТ-инструменты по контролю за виртуальным пространством слишком несовершенны. В частности, вышеуказанное справедливо для специализированных программ, позволяющих осуществлять контрольные мероприятия. В качестве примера можно отметить, что российские программы по контролю виртуального пространства, как и аналогичные зарубежные программы, не позволяют дешифровывать информацию, создаваемую определенными способами кодирования, как, например, сквозное шифрование, что доказывает прецедент с программой «Telegram» (Tereshchenko, 2018:142161). На примере «Великого китайского файрвола» очевидно, что данная и подобные ей программы могут обходиться при помощи VPN-cервисов, что было продемонстрировано одним из разработчиков «Золотого щита», программистом Фан Биньсином, при помощи сервиса Tianhe еще в 2016-м году ${ }^{11}$. Как показывает практика, две указанные проблемы, получение и фильтрация/блокировка определенной информации, являются наиболее существенными в рассматриваемом вопросе. При этом попытки их решения, лежащие в плоскости создания и внедрения более совершенных технологий, требуют значительных финансовых затрат. Об определенных трендах в данной области будет сказано в следующем разделе исследования.

Традиционный для любого государства способ реагирования на правонарушения - привлечение к ответственности виновных лиц применительно к нарушениям в сети «Интернет» существенным образом затруднен, поскольку современные технологии позволяют анонимно совершать правонарушения, находясь в любой точке земного шара, включая такие локации, на которых определенные деяния не являются наказуемыми, в отличие от законодательства тех стран, где они фактически совершаются через «Всемирную паутину». Решать эту проблему, в частности, пытаются посредством выстраивания системы международного сотрудничества и унификации законодательства в сфере противодействия правонарушениям в виртуальном пространстве и контроля над ним. На многостороннем уровне в качестве примера можно привести 108-ю Конвенцию Совета Европы, на двухстороннем уровне - соглашение 2015-го года между Российской Федерацией и КНР об обеспечении информационной

\footnotetext{
${ }^{9}$ См.: официальный сайт МВД России, available at: https://xn--b1aew.xn--p1ai/news/item/19087056 (Accessed 03 March 2020).

${ }^{10}$ См.: официальный сайт ФГУП РАМИ «РИА НОВОСТИ», available at: https://ria.ru/20190522/ 1554794105.html (Accessed 03 March 2020).

${ }^{11}$ См.: официальный сайт газеты «Ведомости», available at: https://www.vedomosti.ru/opinion/articles/ 2018/04/25/767754-kak-ustroen-faeirvol (Accessed 03 March 2020).
} 
безопасности. При этом представляется, что некоторые страны, в частности Российская Федерация, могли бы продвинуться в решении означенной проблемы посредством создания контролируемых некоммерческих организаций международного характера и сети их филиалов в иностранных юрисдикциях, осуществляющих мониторинг виртуального пространства и реагирующих на правонарушения, затрагивающие национальные интересы, создавшего их государства, с учетом специфики законодательства тех стран, в которых они присутствуют, включая меры правового реагирования (например подача заявлений в правоохранительные органы иностранных государств). Посредством общественных организаций можно решать не только проблему привлечения к ответственности за правонарушения в сети «Интернет», но и проблему улучшения «информационной экологии» в виртуальном пространстве, а также правового и культурного просвещения в нем, посредством оставления соответствующих комментариев в социальных сетях и иными схожими способами, чему в настоящее время уделяется недостаточно большое внимание.

Усиление государственного присутствия в виртуальном пространстве важная часть развития информационного общества, поскольку обеспечение национальных интересов представляется без этого очень сложной задачей. На данном пути существенная проблема - репутационные риски государства, связанные с усилением государственного контроля в сети «Интернет». Любое государство, позиционирующее себя в качестве правового, вынуждено балансировать между охранительной политикой, направленной на введение контрольных ограничений, и либеральной политикой, представляющей гражданам определенную степень самостоятельности при реализации ими своих прав и свобод в контексте информационных отношений, возникающих в сети «Интернет». Кроме того, из вышеописанного следует, что в случае слабо обоснованного крена в сторону «охранительной политики» государство рискует своей репутацией в качестве «демократического». Принятие нормативных правовых актов, каким-либо образом ограничивающих возможности пользователей Всемирной компьютерной сети, могут встретить осуждение со стороны: 1) представителей гражданского общества 2) иностранных государств 3) международных организаций. В виде примера подобной ситуации, при которой на трех указанных уровнях государство, применившее строгие меры контроля относительно сферы виртуального пространства, понесло репутационный ущерб, можно озвучить скандал с разоблачениями, сделанными бывшим сотрудником ЦРУ Эдвардом Сноуденом в 2013-м году. Разглашенные им сведения об американской программе PRISM, а также о некоторых иных мероприятиях западных спецслужб, направленных на обеспечение контроля за обменом информацией, происходящем в сети «Интернет», привело к широкому общественному резонансу и повлияло на политический образ США как демократического государства, способного поддерживать свою национальную безопасность и при этом незыблемо соблюдать права человека (Gazizov, 2013: 24-40). По нашему мнению, вышеуказанный скандал, а равно 
аналогичные случаи, можно описать таким термином, как «эффект Сноудена»: ситуация, когда публичное сообщение об усилении государственного контроля за частной жизнью граждан в сети «Интернет» воспринимается со стороны последних как нарушение их конституционных прав, что ведет к росту протестной активности и снижению уровня общественного доверия государству. В целом считаем, что в современных условиях право на неприкосновенность частной жизни должно существовать при условии обеспечения доступа должностных лиц органов государственной власти к создаваемой пользователями сети «Интернет» информации, при условии недопущения произвольного использования такой информации, в том числе с целью ее публичной огласки. Это позволит существенно повысить уровень информационной безопасности. При этом важно придавать легитимность принимаемым решениям.

Имеется проблема вовлечения гражданского общества в процесс контроля за сетью «Интернет». Следует констатировать, что в современном мире существуют общественные организации, деятельность которых состоит в выявлении правонарушений в сети «Интернет» посредством мониторинга содержащейся в ней информации. Например, на базе Общественной палаты Российской Федерации создан мониторинговый центр «Безопасность 2.0», прямая задача которого, - мониторинг Всемирной компьютерной сети на предмет выявления сайтов, содержащих запрещенную информацию, с последующим сообщением о них в Роскомнадзор. Периодически устраиваются мониторинговые рейды и со стороны общественных палат субъектов Российской Федерации ${ }^{12}$. Схожие по своим задачам организации существуют и в других странах. Например, в Великобритании есть организация «Папирус», которая проводит интернетмониторинг с целью закрытия сайтов, пропагандирующих суициды, а также организация «Интернет-наблюдение», которая занимается мониторингом сети на предмет выявления сайтов, содержащих информацию экстремистской направленности. В Канаде подобную деятельность осуществляет некоммерческая организация под названием Канадский центр по защите детей. Организация, занимающаяся мониторингом виртуального пространства для обеспечения информационной безопасности, есть в КНР: Ассоциация кибербезопасности Китая. В условиях глобализации некоторые организации, осуществляющие мониторинг виртуального пространства, носят характер международных. В качестве примера можно привести NetBlocks. C точки зрения сферы контроля все некоммерческие организации можно разделить на два типа: 1) организации, осуществляющие мониторинг виртуального пространства с целью пресечения любой противоправной деятельности; 2) организации, осуществляющие мониторинг виртуального пространства с целью пресечения строго определенных ви-

\footnotetext{
${ }^{12}$ См.: официальный сайт Общественной Палаты Российской Федерации, available at: https://www.oprf. $\mathrm{ru} / \mathrm{ru} /$ press/news/2017/newsitem/42692?PHPSESSID=m1v88m9fnerk651ud8g73pfl95 (Accessed 03 March 2020).
} 
дов противоправной деятельности (например, детская порнография, интернетмошенничество, незаконный оборот наркотических средств и психотропных веществ).

Существует несколько специальных проблем в данной сфере. Прежде всего можно предположить, что представители некоммерческих организаций не могут обладать тем же уровнем компетентности, что и государственные служащие, а это способно приводить к ошибкам при правовой оценке конкретных обстоятельств, низкой эффективности работы. В качестве контраргументов можно отметить, что некоммерческие организации зачастую не обладают тем же широким перечнем полномочий, что и должностные лица органов государственной власти, а нехватку профессиональных навыков можно решить посредством организации соответствующих курсов повышения квалификации. Другая проблема носит больше академический характер. Она состоит в том, что, по мнению некоторых исследователей, институты гражданского общества не должны создаваться со стороны государства, поскольку это противоречит их сути и в таком случае они перестают выражать «народную волю». Однако можно предложить альтернативную концепцию гражданского общества, которую автор условно именует государственной. С точки зрения рационального подхода и в рамках цели, состоящей в обеспечении режима законности в виртуальном пространстве, финансовая (в частности, гранды, субсидии), организационная, административная, медийная поддержка общественных организаций со стороны государства - весьма распространенное явление, примеры которого неоднократно приводятся в настоящей статье. Следует признать, что государство может создавать/участвовать в процессе создания, нужных ему институтов гражданского общества, опираясь на лояльно настроенных по отношению к нему представителей социума, а созданные/функционирующие таким образом некоммерческие организации не выпадают автоматически из орбиты гражданского общества, поскольку, выполняя социальный заказ государства, зачастую способны отражать интересы граждан, равно как и формироваться на добровольной основе со стороны последних, ища при этом на определенном этапе своего развития поддержку у публичной власти для достижения своих целей. С учетом этого проблему эффективности некоммерческих организаций, проводящих мониторинг сети «Интернет», можно решить посредством применения вышеуказанных форм их поддержки со стороны государства.

Отметим следующие итоги настоящего раздела. Выявлены основные проблемы, связанные с реализацией контрольной функции в сети «Интернет»: активный рост правонарушений, совершаемых с использованием сети «Интернет»; несовершенство механизмов и технологий контроля в сфере виртуального пространства; рост общественного недовольства, связанного усилением государственного контроля в сети «Интернет»; трудности привлечения институтов гражданского общества к процессу отправления контроля в сети «Интернет». 


\section{Прогнозирование развития функции государства в области контроля за сетью «Интернет»}

В новейшей истории отправная точка тренда на усиление государственного контроля в сети «Интернет» имеет место уже в самом начале XXI века, что, по нашему мнению, связано с США, и выражается в принятии администрацией Джорджа Буша «Патриотического акта» 2001 года как ответа на события «9/11». Данной практики придерживаются и многие другие страны, например Российская Федерация и КНР. Полагаем, что с учетом возрастающей роли Всемирной компьютерной сети в информационном обществе, а также актуальности исходящих от нее угроз в ближайшие десятилетия будет происходить усиление контрольной функции государства в сфере виртуального пространства.

Несмотря на большие финансовые затраты, будут иметь место значительные бюджетные вложения в разработку программ, позволяющих осуществлять реализацию контрольной функции в виртуальном пространстве. Данный процесс будет тесно связан с вопросами обеспечения государственного суверенитета в сети «Интернет». Полагаем, что многие страны прямо обяжут подконтрольных им субъектов устанавливать вышеуказанные программы на гаджеты и иное оборудование, обеспечивающее доступ к сети. Применительно к Российской Федерации подобная мера возможна в рамках реализации положений Федерального закона от 02.12.2019 № 425-Ф3 «О внесении изменения в статью 4 Закона Российской Федерации “О защите прав потребителей”», которым предписывается обязательная предварительная установка российского ПО на гаджеты, реализуемые в рамках договоров купли-продажи на территории Российской Федерации, согласно перечню, утверждаемому со стороны властей. В подобный перечень вполне возможно включение и указанных программ. В наиболее радикальных случаях будут иметь место попытки обеспечения полной подконтрольности своего виртуального пространства или по крайней мере автономности «национального интернета» от внешней сети, как это сейчас имеет место в Российской Федерации в рамках «Закона о суверенном интернете», а также в КНР, где пристально изучается опыт КНДР в указанном вопросе. Приведем и иные примеры: в Мьянме доступ в сеть «Интернет» возможен только в лицензируемых «интернет-кафе», контролируемых правительством; в Туркменистане во всей стране существует только один разрешенный провайдер, подконтрольный государству (Dashyan, 2007:288).

В данной связи будет развиваться тенденция, состоящая в увеличении перечня обязанностей информационных посредников, связанных с обеспечением возможности отправления государственного контроля в сети «Интернет» и установления режима законности в виртуальном пространстве, а также ужесточаться ответственность за их неисполнение. В качестве примера приведем законодательство ЕС. В 2019-м году получила одобрение Директива Европейского парламента и Совета об авторском праве и смежных правах в рамках еди- 
ного цифрового рынка, в которой имеется статья 13, получившая название «фильтр загрузок» и предусматривающая обязанность владельцев онлайнплатформ устанавливать программные фильтры, обеспечивающие предотвращение нарушений авторских прав в сети «Интернет». Примечательно, что данная статья стала одной из наиболее спорных в указанном документе, наряду со статьей 11, получившей название «налог на ссылки» (закрепляет обязанность интернет-платформ платить отчисления изданиям за цитирование их материалов) (Eremenko, 2019: 9-22).

Как следствие, неизбежна тенденция периодической критики государств со стороны пользователей сети «Интернет», равно как и рост их недовольства в связи с ужесточением контроля в виртуальном пространстве. Страны часто будут сталкиваться с «Эффектом Сноудена». Решение проблемы возможно посредством выстраивания эффективной системы работы с общественным мнением, направленной на формирование позиции о необходимости государственного контроля в сети «Интернет» с точки зрения интересов не только государства, но и общества (Strukov, 2016:142-144).

На уровне межгосударственного взаимодействия и геополитических объединений будет укрепляться сотрудничество и происходить унификация законодательства в области противодействия правонарушениям с использованием информационно-телекоммуникационных технологий.

Как отголосок вышеуказанных вопросов, возможно, что постепенно будет выстраиваться система некоммерческих организаций, участвующих в мониторинге Всемирной компьютерной сети. Данная система должна включать в том числе и межгосударственный аспект. Это может выражаться в росте числа международных организаций, изначально созданных на базе одной или нескольких стран, которые будут заниматься указанной деятельностью на постоянной основе. С другой стороны, возможно появление некоммерческих организаций, выступающих за свободу сети «Интернет» от государственного контроля и обеспечение «информационной экологии», что может, в частности, использоваться для воспрепятствования процессу развития стран их конкурентами, а также увеличения их репутационных издержек при усилении такого контроля посредством формирования в них негативного общественного мнения (Strukov, 2016:267-270).

Таким образом, в настоящем разделе дан прогноз развития контрольной функции государства в сфере виртуального пространства, который по объективным причинам происходит в направлении ее усиления.

\section{Заключение}

Контрольная функция в сфере виртуального пространства - данность, существующая для всех сильных и технологически развитых государств современности. Ее появление - ответ на глобальные проблемы XXI века, решение 
которых требует государственного присутствия и усиления контроля в сети «Интернет». Как следствие указанной функции присущи характерные признаки, цель и формы осуществления. Процесс ее развития сопровождается проблемами, одна из которых - необходимость постоянного совершенствования информационно-телекоммуникационных технологий для отправления контрольной деятельности, что требует значительных затрат. В целом для предотвращения угроз информационной безопасности государству необходимо ужесточать контроль в сфере виртуального пространства. При этом усиление государственного контроля в сети «Интернет» зачастую негативно воспринимается со стороны общества, в связи с чем существует запрос на дополнительные механизмы легитимации государственно-властных решений в указанной сфере.

Об авторе:

Струков Константин Викторович - кандидат юридических наук, сотрудник юридического отдела в ит-компании

ORCID ID: 0000-0002-0592-8807

e-mail: konstantinstrukov@gmail.com 